dicarboxylic acids, thioglucose and the $\mathrm{O}$-glucoside of dithioglycerol ${ }^{5}$. The last of these compounds, given the name $B A L$-Intrav, proved to be the most promising, and has now been shown to have the following properties: (1) The lethal dose (L.D.50) to rats is about $7.5 \mathrm{gm}$. per kilo. (2) It penetrates very slowly into cells, so that its effective distribution in the body is in the blood and intercellular fluids. It is rapidly excreted in the urine. (3) At a dosage of 1-2 gm. per kilo it causes no pathological symptoms in rats, rabbits, guinea pigs or goats, other than a transient increase in rate of respiration. (4) With all four species it gives marked protection against systemic lewisite poisoning. (5) With rabbits, which were studied in most detail, a total dosage of $1.5 \mathrm{gm}$. per kilo of $B A L$-Intrav administered by intravenous injection at intervals over 6 hours will give complete protection against 3-4 times the L.D. ${ }_{50}$ of lewisite, even when four hours elapse between contamination and commencement of treatment.

The lewisite dosage (three to four times the L.D..$_{0}$ ) in the case of rabbits was approximately an L.D.95, that is, it killed 95 per cent of the animals in the absence of therapy. The animal's died between 10 and 48 hours after contamination. If treatment was delayed for $6 \frac{1}{2}$ hours after contamination, about 50 per cent of the animals could be saved. It was thought that the mortality of 50 per cent when therapy was delayed for $6 \frac{1}{2}$ hours might be due to tardy removal of arsenic from intracellular sites. It seemed likely that the rate of removal could be increased by giving a small amount of a cell-permeating thiol, such as dithioglycerol $(B A L)$, which could act as a carrier of arsenic between the cell and the $B A L$-Intrav in the blood. This proved to be the case; a dose of $4 \mathrm{mgm}$. per kilo of $B A L$, when given with a high dosage (1-1.5 gm. per kilo) of BAL-Intrav, reduced the mortality under the conditions given above to 25 per cent when treatment was delayed for $6 \frac{1}{2}$ hours after contamination. A dose of $4 \mathrm{mgm}$. per kilo of $B A L$ produces only transient signs of toxicity, and when given without $B A L$-Intrav did not reduce mortality at all ${ }^{6}$.

Prof. R. A. MeCance and Dr. E. M. Widdowson have kindly made intravenous injections of $B A L$ Intrav into a number of men, observing no ill effects with a dose of about $100 \mathrm{mgm}$. per kilo, given as a single intravenous dose. The maximum permissible single dose of $B A L$ is $4 \mathrm{mgm}$. per kilo, at which level some pathological complications appear. (This dose may, however, be repeated at intervals of four hours.)

Those engaged on this problem are deeply indebted to many friends at Oxford, Cambridge and at the Ministry of Supply, both in London and at Porton : the list of names involved is too long to mention here, but an exception must be made in the case of Prof. G. R. Cameron, without whose sympathetic advice and generous practical assistance we should not have accomplished this work. This work was commenced while three of us (J. F. D., M. D. and P. D. M.) were members of a team under the administration of Dr. M. Dixon. We are indebted to the Chief Scientific Officer, Ministry of Supply, for permission to publish this report.

${ }^{1}$ Cameron, Short, Mitchell and Danielli. Report to Ministry of Supply, 1943.

'Mitchell, Danielli and Short, Report to Ministry of Supply, 1944.

Peters, Stocken and Thompson, Nature, 156, 616 (1945).

- Danielli, in "Cytology and Cell Physiology" (ed. Bourne, 1942).

${ }^{5}$ Danielli, Danielli, Mitchell, Owen and Shaw, Report to Ministry of Supply, 1944.

' Danielli, Jones and Mitchell, Report to Ministry of Supply, 1945.

\section{AMERICAN WORK ON BAL}

7 HE brief review in these columns (Nature, 156, $616 ; 1945)$ by Peters, Stocken and Thompson giving the history of the discovery and outlines of work upon $2: 3$ dimercaptopropanol ( $B A L$, or British antilewisite), has now been amplified by a statement from the United States (Science, 102, 601; 1945) ably compiled by L. L. Waters and Chester Stock. In the previous article, the main facts were given of the biochemical work leading up to this discovery, and the evidence was briefly summarized for the view that vicinal dithiols are effective antidotes to arsenic through their ability to form ring compounds with trivalent arsenicals, permitting thereby the excretion of increased amounts of arsenic from the system. In the American review, an account is given of the intense programme of study undertaken jointly by various U.S. Government agencies into the preparation and manufacture, biochemistry, toxicology, pharmacology, experimental therapeutics and clinical application of the new discovery.

In addition to confirming and extending the funda. mental British observation, American workers have shown how trypanosomes and spermatozoa poisoned with arsenic can be revived by dithiols of $B A L$ type, with presumptive elimination of the arsenic. They have studied in detail the action of $B A L$ as a reducing agent, finding that it converts methæmoglobin instantaneously to hæmoglobin, and in the presence of oxygen will open the porphyrin ring. Among the pharmacological facts recorded, it has been found that lethal amounts of $B A L$ cause an intense vasocon. striction in skin and skeletal muscle with early transient rise in blood pressure; there is also a reduc. tion in $p H$ of the blood. In an analysis of the toxicity of the compound when injected in amounts approach. ing a lethal dose, it was also shown that by keeping cytochrome $C$ in a reduced condition it can interfere with cytochrome oxidase activity, and that oxidized $B A L$ can act as an inhibitor of enzymes containing - SH groups essential for their activity.

It is perhaps worth stressing that, despite these toxic actions produced by high concentrations of the drug, $B A L$ dissolved in peanut-oil has now been injected safely and with favourable results into a large number of patients suffering from arsenical dermatitis both in Great Britain and in the United States. It is stated that animal experiments have shown that $B A L$ can prevent the development of pulmonary lesions not only after the inhalation of lewisite, but also after cadmium and zinc fumes; and that it is also active against the systemic action of mercury. Preliminary therapeutic trials in mercury poisoning have been encouraging. The detailed publications will be awaited with interest.

\section{OBITUARIES}

\section{Sir Farquhar Buzzard, Bart., K.C.V.O.}

Sir FarquHAR Buzzard died at Oxford of coronary thrombosis on December 17 in his seventy-fourth year. Like his father, Dr. Thomas Buzzard, of the National Hospital, Queen Square, he was a distin. guished neurologist. After graduation from Oxford and St. Thomas's Hospital, he became house physician at Queen Square to the great Hughlings Jackson, an old friend of his family. He was elected to the staff at Queen Square in 1905, and later to St. Thomas's. 
His published contributions to neurology consist of a well-known book on the "Pathology of the Nervous System" (with J. G. Greenfield) and numerous articles and lectures on clinical subjects, including the Goulstonian and Lettsomian Lectures and the Harveian Oration. These reveal him as a keen clinical observer, with a deep understanding of the psychological aspects of illness. He was, indeed, a pioneer among organic neurologists in recognizing the importance of minor psychological ailments and their relationship to the major psychoses, at a time when it was considered at Queen Square that a neurologist ought not to concern himself with the functional side of neurology. His opinion on difficult cases was much sought, for he had to a marked degree the qualities of a good consultant : he was imperturbable yet sympathetic, direct and honest with patient and medical man alike--and with himself in his own unobtrusive way; and he had a strong constitution and great physical and moral endurance.

In 1928 at the height of his fame as a London consultant, Buzzard succeeded Sir Archibald Garrod as regius professor of medicine at Oxford, a position which he held for the next fifteen years. He had expected to be able to continue some consultant work from Oxford, but soon found this impossible. $\mathrm{He}$ served on the Hebdomadal Council and on numerous University committees, and was chairman of the honorary medical staff committee and later vice. president of the Radcliffe Infirmary. In these various capacities he notably influenced University policy in general, and the development of the medical school in particular.

In administrative affairs his talents lay rather in the field of conciliation and in giving cohesion to the ideas of his colleagues than as an originator. He was the engineer of Lord Nuffield's medical benefactions, the Institute of Medical Research (1935) and the scheme for enlarging the scope of the medical school (1937). It was under his guidance that an undergraduate clinical school was opened at the outbreak of war when Oxford students had nowhere else to go for clinical instruction. He was the first chairman of the medical committee of the Nuffield Provurcial Hospitals Trust, and was largely instrumental in directing its activities into the field of social medicine. In committee he could be slow and even ponderous (a manner occasionally belied by a quick flash of wit), and his patience was inexhaustible; the only sign of anger was a slight flushing of his sturdy neck and a steely glint of his eyes. He was reserved, perhaps more taciturn than the ideal University democrat, and for all his rugged honesty he was not without his moments of artfulness (as was most evident on the tennis court); but he retained to the end of his life a great tolerance and understanding of younger men, and was generously loyal to them even when they contrived to hurt his feelings.

The University of Oxford awarded Sir Farquhar the Osler Memorial Medal, he was an honorary fellow of his old college Magdalen, and after his retirement in 1943, honorary student of Christ Church; he was Extra Physician to H.M. the King and had many honours.

His last year was characteristic of him : in his work for the Hospitals Trust, though beginning to feel his years, he travelled the country in more discomfort than most men of his age would have supported. A severe heart attack in the late summer was met with his customary stoicism, his one fear being that he might live and yet not be able to work. He died suddenly before the fear was realized. H. CaIRns.

\section{Dr. L. Cernosvitov}

Tere sudden death of Dr. Lev Cernosvitov on December 15 came as a sad shock to his friends and colleagues. He was well known as a specialist on Oligochæte worms, a group which he had made his own and on which he had produced a body of work of the highest standard.

Lev Vladimirovich Cernosvitov was born in Poltava in July 1902. A few years of his early child. hood were spent in Paris, where his father, a member of the legal profession, was in exile for revolutionary activities. The family were back in Russia, however, for his school years, which were interrupted by the revolution of 1917. In 1920, at the age of eighteen, he escaped to Constantinople; and two years later he was taken, with a number of other Russian youths, to Prague, where he received his higher education, taking his doctorate in zoology in 1927.

Cernosvitov's first paper on Oligochætes was published in 1925 in collaboration with Sergej Hrabr, and from then on a steady stream of papers on this group came from his pen. Much of the material described was collected by himself in Czechoslovakia, in the Carpathians, in the Balkans and in South America. The American collections were made during 1931-32 when Cernosvitov was engaged in work on the control of insect agricultural pests, and the three interesting papers on this material that appeared in 1936, 1937 and 1942 were to have been followed by a more comprehensive work when opportunity allowed. On his return from South America, besides having to earn his living by more utilitarian tasks (experimental transplantation of teeth of mice in a dental clinic, field-work for the biological control of the spruce saw-fly, etc.), Cernosvitov was now much in demand to report upon the Oligochæte collections of many expeditions and European museums. His connexion with England occurred in a double capacity. His work on spruce saw-flies was done for the Imperial Institute of Entomology, and, after Colonel J. Stephenson's death in 1933, we looked to him for all expert work on Oligochæta. The late Rev. Hilderic Friend sent him his collections of Enchytræidæ, upon which Cernosvitov reported in 1937. The late Charles Monro, who had charge of the annelid worms at the British Museum (Natural History), was very anxious to attach him to the Museum staff as Oligochæte specialist. In $\mathbf{1 9 4 5}$ he was elected fellow of the Linnæan Society.

When war broke out in 1939, Cernosvitov was pursuing saw-fly parasites in Finland. He hurried to London, and until July 1940 was working at the Museum. Owing to war conditions, he then had to accept a post as monitor at the B.B.C., where his linguistic attainments were of value. With great determination he kept in touch with 'his worms'. He spent one of his short holidays at Bangor, where his first contact with the teeming life of the intertidal zone gave him a thrill similar to that he experienced on first meeting the tropical fauna. In 1943 he spent a couple of weeks at the Freshwater Biological Association's station on Windermere. The collections made there were later worked out at the University of Reading in his free time from B.B.C. duties, and a paper on them appeared in the Proceedings of the Zoological Society of 1945. This work, and a revision of Friend's types published in 1942, put British Oligochrte studies on a sound basis.

In addition to his anatomical and taxonomic work, 